\title{
Effects of land cover change on temperature and rainfall extremes in multi-model ensemble simulations
}

\author{
A. J. Pitman ${ }^{1}$, N. de Noblet-Ducoudré ${ }^{2}$, F. B. Avila ${ }^{1}$, L. V. Alexander ${ }^{1}$, J.-P. Boisier ${ }^{2}$, V. Brovkin ${ }^{3}$, C. Delire ${ }^{4}$, \\ F. Cruz ${ }^{5,1}$, M. G. Donat ${ }^{6}$, V. Gayler ${ }^{3}$, B. van den Hurk ${ }^{7}$, C. Reick ${ }^{3}$, and A. Voldoire ${ }^{4}$ \\ ${ }^{1}$ ARC Centre of Excellence for Climate System Science, University of New South Wales, Sydney, Australia \\ ${ }^{2}$ Laboratoire des Sciences du Climat et de l'Environnement, Gif-sur-Yvette, France \\ ${ }^{3}$ Max Planck Institute for Meteorology, Hamburg, Germany \\ ${ }^{4}$ Groupe d'étude de l'Atmosphère Météorologique, Toulouse, France \\ ${ }^{5}$ Manila Observatory, Quezon City, Philippines \\ ${ }^{6}$ Climate Change Research Centre, University of New South Wales, Sydney, Australia \\ ${ }^{7}$ Royal Netherlands Meteorological Institute, De Bilt, The Netherlands
}

Correspondence to: A. J. Pitman (a.pitman@unsw.edu.au)

Received: 14 June 2012 - Published in Earth Syst. Dynam. Discuss.: 17 July 2012

Revised: 16 October 2012 - Accepted: 22 October 2012 - Published: 26 November 2012

\begin{abstract}
The impact of historical land use induced land cover change (LULCC) on regional-scale climate extremes is examined using four climate models within the Land Use and Climate, IDentification of robust impacts project. To assess those impacts, multiple indices based on daily maximum and minimum temperatures and daily precipitation were used. We contrast the impact of LULCC on extremes with the impact of an increase in atmospheric $\mathrm{CO}_{2}$ from $280 \mathrm{ppmv}$ to 375 ppmv. In general, consistent changes in both high and low temperature extremes are similar to the simulated change in mean temperature caused by LULCC and are restricted to regions of intense modification. The impact of LULCC on both means and on most temperature extremes is statistically significant. While the magnitude of the LULCCinduced change in the extremes can be of similar magnitude to the response to the change in $\mathrm{CO}_{2}$, the impacts of LULCC are much more geographically isolated. For most models, the impacts of LULCC oppose the impact of the increase in $\mathrm{CO}_{2}$ except for one model where the $\mathrm{CO}_{2}$-caused changes in the extremes are amplified. While we find some evidence that individual models respond consistently to LULCC in the simulation of changes in rainfall and rainfall extremes, LULCC's role in affecting rainfall is much less clear and less commonly statistically significant, with the exception of a consistent impact over South East Asia. Since the simulated response of mean and extreme temperatures to LULCC is
\end{abstract}

relatively large, we conclude that unless this forcing is included, we risk erroneous conclusions regarding the drivers of temperature changes over regions of intense LULCC.

\section{Introduction}

The Land Use and Climate, IDentification of robust impacts (LUCID) project (de Noblet-Ducoudré et al., 2012) is a major international effort to understand the biophysical impacts of land use induced land cover change (LULCC). LUCID focussed on one major type of LULCC: conversion of land between forests, pasture and crops. LUCID used 7 global climate models with prescribed boundary conditions to examine how LULCC affected the regional and global mean surface climate. How LULCC affects land-atmosphere interactions is complex because a major change to land cover has competing impacts. LULCC, in the form of clearance for crops and pasture, affects net radiation and the partitioning of available energy at the surface. Since conversion of native vegetation to crops and pasture typically increases albedo, it reduces net radiation (Forster et al., 2007) which tends to cool the surface. However, changes in leaf area index, aerodynamic roughness length, stomatal conductance and the seasonality of vegetation cover also tend to decrease evapotranspiration and increase sensible heat fluxes (Bala et al., 
2007; Pitman et al., 2009). This change in the surface energy balance can lead to regional scale warming. In the context of LUCID, de Noblet-Ducoudré et al. (2012) and Boisier et al. (2012) provide an in-depth analysis of these issues.

In general, the albedo effect tends to dominate over the mid-latitudes, enhanced by increases in snow cover, while the role of evapotranspiration and aerodynamic roughness length tends to dominate over the tropics (Davin and De Noblet-Ducoudré, 2010). Hence, in terms of the averages, the biophysical impact of LULCC is to typically warm the tropics and cool the mid-latitudes (Lawrence and Chase, 2010). This difference in the sign of the impact of regional LULCC results in negligible changes in key climate variables, such as temperature and rainfall, when averaged globally (Feddema et al., 2005; Pielke et al., 2011). At regional scales, however, in regions subjected to significant LULCC, the impact of landscape change on temperature and some hydrometeorological variables can be similar in magnitude to a doubling of atmospheric $\mathrm{CO}_{2}$ (Zhao and Pitman, 2002; Voldoire, 2006) or other large-scale changes in forcing such as the El NiñoSouthern Oscillation (Findell et al., 2009). There is also a complex interaction between changes in rainfall, snowfall and/or temperature and the impact of LULCC, particularly under elevated $\mathrm{CO}_{2}$ (Pitman et al., 2011). A detailed examination of the observational and model-based evidence linking LULCC to local, regional and global scale climate has recently been provided by Pielke et al. (2011).

While a focus on how LULCC affects global and regional mean surface climate is understandable (at the annual, seasonal and interannual time scales), there is also a need to examine how climate extremes are affected by landscape change. Observations demonstrate that extremes are changing (IPCC, 2012). Since the middle of the 20th century there has been a positive (warming) shift in the distribution of daily minimum temperature throughout the globe (Caesar et al., 2006), manifested by a significant increase in the number of warm nights globally (Alexander et al., 2006). A positive shift in the distribution of daily maximum temperature has also been observed, although somewhat smaller than the increase in daily minimum temperature. There have also been statistically significant trends in the number of heavy precipitation events in some regions (IPCC, 2012).

LULCC also affects extremes (Pielke et al., 2011). The nature of the land surface affects the capacity to supply water to be evaporated at the surface and this can amplify or suppress meteorologically driven extremes. For example, Teuling et al. (2010) highlighted how forest and grassland regions of Europe responded to heatwaves, identifying a stronger drought control by forests compared to grassland. Stefanon et al. (2012) demonstrated considerable sensitivity in these phenomenon associated with how vegetation phenology is represented. Once linked with the impact of LULCC on landatmosphere coupling (Seneviratne et al., 2006, 2010) and the recognition that the surface energy balance is strongly affected by the nature of the land cover (Pitman, 2003; Bonan,
2008; Levis, 2010; Boisier et al., 2012) it is plausible that LULCC could affect temperature extremes provided it is of a sufficient scale and intensity.

There is also a potential link between LULCC and rainfall extremes (Pielke et al., 2011) either directly via a change in the land forcing on the boundary layer (Pielke, 2001; Niyogi et al., 2011) or via impacts on horizontal temperature gradients and advection of heat and moisture (Gero and Pitman, 2006; Chang et al., 2009).

As noted earlier, LUCID's experimental design focussed on the conversion of land between forests, pasture and crops. The LULCC perturbations used in this paper therefore omit at least two major forms of LULCC that are also known to be important to local and regional climate and that might have impacts beyond the areas affected by land cover change. Urbanization is well known to affect the near-surface air temperature and moisture fluxes strongly (Arnfield, 2003) and affects minimum air temperatures more than the maximum under specific synoptic conditions. Urbanization can also affect rainfall and rainfall extremes (Shepherd, 2005). Irrigation also affects both seasonal mean and extreme temperatures and may affect rainfall (DeAngelis et al., 2010) in some regions in some seasons (Douglas et al., 2009; Lobell et al., 2009; Puma and Cook, 2010). LUCID omitted these types of LULCC because these processes are not routinely parameterized in land surface models and we wanted to include as many individual models as possible. However, as a consequence of not representing urbanization and irrigation the impacts of LULCC on extremes is likely underestimated in some regions.

To explore the impacts of LULCC on extremes, Avila et al. (2012) used a coarse resolution global climate model and examined the simulated daily maximum and minimum temperature. They followed the recommended methods from the joint Commission for Climatology (CCL), the Climate Variability and Predictability (CLIVAR) Programme of the World Climate Research Programme (WCRP) and the Joint World Meteorological Organization-Intergovernmental Oceanographic Commission Technical Commission for Oceanography and Marine Meteorology (JCOMM) Expert Team on Climate Change Detection and Indices (ETCCDI) (Alexander et al., 2006). Due to the coarse resolution of the model, they did not examine changes in precipitation. This paper extends the study by Avila et al. (2012) in two ways. First, we report on the impact of LULCC (in the form of the conversion of land between forests, pasture and crops) over four different global climate models to produce a more reliable estimate than Avila et al. (2012). Second, we use climate models with a finer spatial resolution. We therefore also include the impact of LULCC on rainfall extremes, although we are cautious in our interpretation of these results given the challenge of simulating accurate rainfall statistics in global climate models. 
Table 1. List of climate models and associated Land Surface Models used in the first LUCID set of experiments.

\begin{tabular}{llrll}
\hline Climate model & Reference & Spatial resolution & Land surface model & Reference \\
\hline ARPEGE & Salas-Mélia et al. (2005) & $2.8^{\circ} \times 2.8^{\circ}$ & ISBA & Voldoire (2006) \\
ECHAM5 & Roeckner et al. (2006) & $3.75^{\circ} \times 3.75^{\circ}$ & JSBACH & Raddatz et al. (2007) \\
ECEarth & www.ecmwf.int/research/ifsdocs/CY31r1/ & $1.8^{\circ} \times 1.8^{\circ}$ & HTESSEL & Hazeleger et al. (2011) \\
IPSL & Marti et al. (2010) & $2.5^{\circ} \times 3.75^{\circ}$ & ORCHIDEE & Krinner et al. (2005) \\
\hline
\end{tabular}

Table 2. Description of simulations performed by each climate model.

\begin{tabular}{|c|c|c|c|c|}
\hline $\begin{array}{l}\text { Experiment } \\
\text { Name }\end{array}$ & Description of the experiment & $\begin{array}{r}\mathrm{CO}_{2} \\
(\mathrm{ppmv})\end{array}$ & $\begin{array}{r}\text { Year of } \\
\text { vegetation map }\end{array}$ & SSTs \\
\hline PI & $\begin{array}{l}\text { Pre-industrial simulation, with } \mathrm{CO}_{2} \text {, } \\
\text { greenhouse gases, aerosols, land cover } \\
\text { map and SSTs being prescribed at their } \\
\text { pre-industrial values }\end{array}$ & 280 & 1870 & Prescribed 1870-1900 \\
\hline PD & $\begin{array}{l}\text { Present-day simulation, with present-day } \\
\mathrm{CO}_{2} \text {, land cover map, SSTs and sea ice } \\
\text { extent. Other greenhouse gases have been } \\
\text { added to the } \mathrm{CO}_{2} \text { concentration as } \mathrm{CO}_{2}- \\
\text { equivalent*, while aerosols have been } \\
\text { kept to their pre-industrial values. }\end{array}$ & 375 & 1992 & Prescribed 1972-2002 \\
\hline PIv & $\begin{array}{l}\text { Pre-industrial simulation with } \mathrm{CO}_{2} \text {, } \\
\text { greenhouse gases, aerosols and SSTs } \\
\text { being prescribed at their pre-industrial } \\
\text { value, but with present-day land cover } \\
\text { map }\end{array}$ & 280 & 1992 & Prescribed 1870-1900 \\
\hline PDv & $\begin{array}{l}\text { Present-day simulation, with present-day } \\
\mathrm{CO}_{2} \text {, SSTs and sea ice extent. Other } \\
\text { greenhouse gases have been added to the } \\
\mathrm{CO}_{2} \text { concentration as } \mathrm{CO}_{2} \text {-equivalent, } \\
\text { while aerosols have been kept to their pre- } \\
\text { industrial values. Land cover map is pre- } \\
\text { industrial. }\end{array}$ & 375 & 1870 & Prescribed 1972-2002 \\
\hline
\end{tabular}

* Except in EC-EARTH where those were changed proportionally to $\mathrm{CO}_{2}$ changes.

\section{Methodology}

\subsection{Experimental design}

Four climate models coupled to different land surface models were used (Table 1). These are a sub-set of the models reported by de Noblet-Ducoudré et al. (2012) because the calculation of the ETCCDI indices requires daily data and only these four modelling groups saved daily temperature and rainfall data. Details of the models used, the land surface schemes and how LULCC was implemented in each modelling system are provided by de Noblet-Ducoudré et al. (2012). We omit results from Avila et al. (2012) because they did not use the LUCID experimental design.

All models undertook simulations representing present day and pre-industrial greenhouse gas concentrations and sea surface temperatures (SSTs) (Table 2). Both SSTs and sea ice extent were prescribed to vary interannually and seasonally using the Climate of the 20th Century project specifications (see HadISST1.1, ftp://www.iges.org/pub/kinter/c20c/ HadISST/). Each model undertook simulations forced with two different vegetation distributions (representative of 1870 or 1992) and carried out at least 5 independent simulations for each experiment to help determine those changes that were robust from those that reflected internal model variability. The independent simulations were combined (not averaged) before calculating the indices. Hence, each member of an ensemble is accounted for in calculation of the indices and in the calculation of the statistical significance of changes in the extreme indexes.

For the vegetation distribution, each model was provided the same distribution of crop and pasture at a resolution of $0.5^{\circ} \times 0.5^{\circ}$ obtained respectively from Ramankutty and 

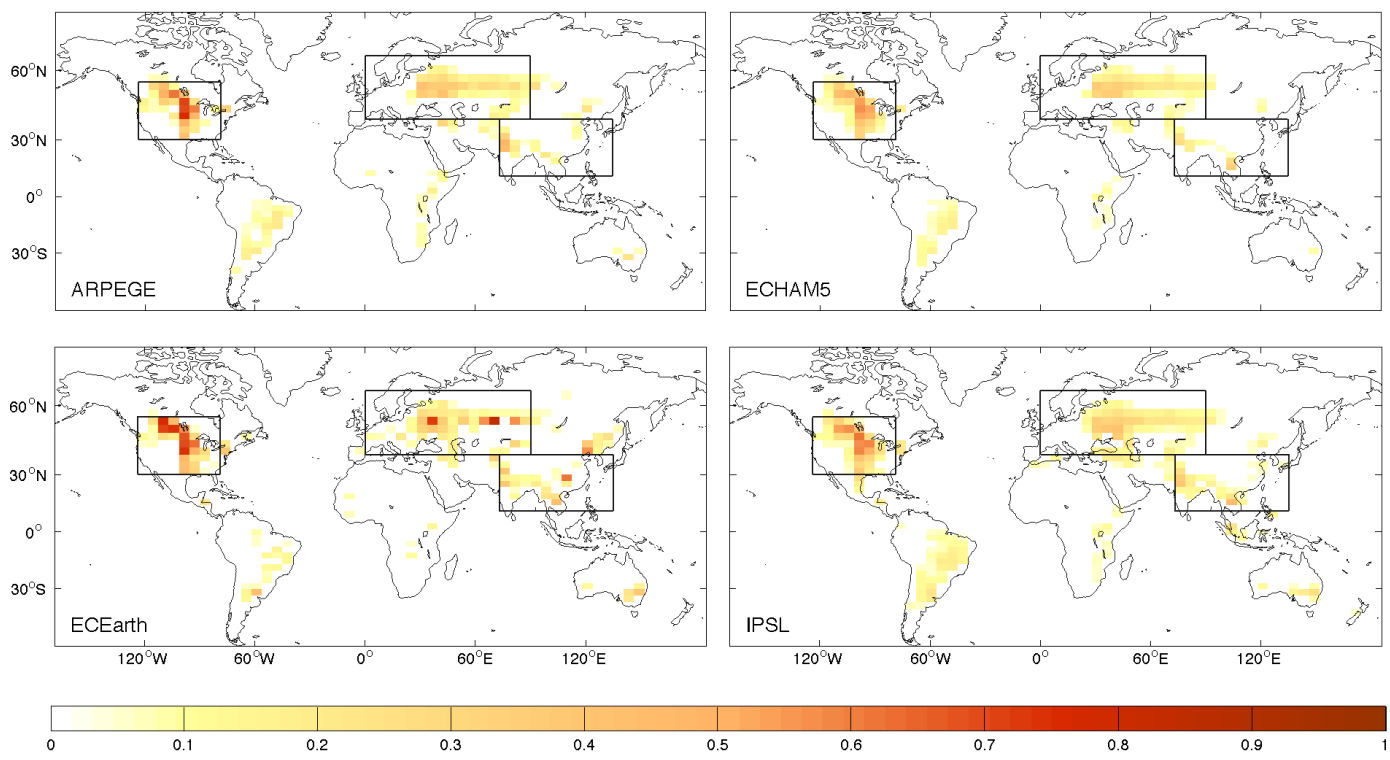

Fig. 1. Fraction of vegetation cover converted from natural vegetation to cropland for the four models. The boxes on each panel outline the

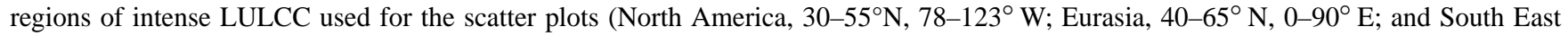
Asia, $\left.11-40^{\circ} \mathrm{N}, 73-135^{\circ} \mathrm{E}\right)$.

Foley (1999) for crops and Goldewijk (2001) for pasture, and each group imposed this crops and pasture distribution onto their existing vegetation map. Natural vegetation for each map, and therefore each group, at each time period (1870 or 1992) therefore either comes from a potential vegetation map, or from an enlargement/contraction of present-day natural vegetation, while the extent of crops and pasture comes from the datasets provided. Note that the scale of croplands is geographically quite extensive but the intensity of croplands only exceeds $50 \%$ over large areas in eastern United States, Western Europe and parts of South East Asia. However, the intensity of LULCC varies between the four climate models (Fig. 1) despite the use of the same input data sets because each modelling group implemented the area of cropland and pasture independently (see de Noblet-Ducoudré et al., 2012).

Our experiments are conducted as follows. We represent the change due to $\mathrm{CO}_{2}$ via the difference between simulations using near present day $\mathrm{CO}_{2}(375 \mathrm{ppmv})$ with land use representing 1870 (experiment PDv) differenced from simulations using an identical configuration, except $\mathrm{CO}_{2}$ was set to $280 \mathrm{ppmv}$ (experiment PI). Thus PDv-PI, which both use 1870 land use, captures the impact of a change in $\mathrm{CO}_{2}$. A second set of results examines the impact of LULCC. To examine the impact of LULCC at 280 ppmv, experiments are undertaken with 1992 land use (experiment PIv) and 1870 land use (experiment PI) and are represented by the difference PIv-PI. A parallel experiment at 375 ppmv is also conducted with land use representing 1992 (experiment PD) and 1870 (experiment PDv) represented by the difference PDPDv. Details on the experiment configuration are provided in Table 2.

\subsection{Extreme indices}

We used the ETCCDI indices in this paper. They are calculated from daily maximum and minimum temperature and daily precipitation, and have been developed to assess changes in intensity, duration and frequency of extreme climate events. While the ETCCDI indices do not always represent the largest extremes, they provide globally coherent measures of more moderate extremes that can be useful for global climate change impact assessments (Klein Tank and Zwiers, 2009; Zhang et al., 2011). Details of the indices used in this study are provided in Table 3.

To derive the indices, the simulation PI was used as the reference distribution. For each model and each experiment, all 5 runs were concatenated (combined into a single data set) before the indices were calculated. For indices based on percentiles (TN10p, TX10p, TN90p, TX90p, CSDI, WSDI), the daily 10th and 90th percentiles from the PI simulation are also used as thresholds when calculating the indices for the other simulations (i.e. PIv, PD, PDv). To aid comparison between the models, the daily temperature and precipitation data were interpolated to a common grid before calculating the indices.

\subsection{Assessing local significance}

Since the distribution of the indices is not necessarily Gaussian, a parametric test such as Student's t-test may be inappropriate for testing the null hypothesis so there is no statistically significant difference between the simulations for a given index. We therefore use the two-tailed KolmogorovSmirnov test, which is a non-parametric test that makes no 
Table 3. A selection of the temperature indices recommended by the ETCCDI and used in this study (definitions can be found at http://cccma.seos.uvic.ca/ETCCDI/list_27_indices.shtml). Note that ETCCDI expresses the temperature frequency indices (TX10p, TN10p, TX90p and TN90p) in percentages, but the scale used here is in number of days per 3-month season (DJF, MAM, JJA, SON). Differences in the percentile-based indices (including WSDI and CSDI) relate to the 10th and 90th percentiles of simulation PI.

\begin{tabular}{|c|c|c|c|}
\hline Index & & Definition & Unit \\
\hline & $\begin{array}{l}\text { A. Temperature } \\
\text { Intensity }\end{array}$ & & \\
\hline TXn & Min Tmax & Coldest seasonal daily maximum temperature & ${ }^{\circ} \mathrm{C}$ \\
\hline $\mathrm{TNn}$ & Min Tmin & Coldest seasonal daily minimum temperature & ${ }^{\circ} \mathrm{C}$ \\
\hline TXx & Max Tmax & Warmest seasonal daily maximum temperature & ${ }^{\circ} \mathrm{C}$ \\
\hline \multirow[t]{2}{*}{$\mathrm{TNx}$} & Max Tmin & Warmest seasonal daily minimum temperature & ${ }^{\circ} \mathrm{C}$ \\
\hline & Duration & & \\
\hline CSDI & $\begin{array}{l}\text { Cold spell } \\
\text { duration indicator }\end{array}$ & $\begin{array}{l}\text { Annual number of days with at least } 6 \text { consecutive } \\
\text { days when Tmin }<10 \text { th percentile }\end{array}$ & Days per year \\
\hline \multirow[t]{2}{*}{ WSDI } & $\begin{array}{l}\text { Warm spell } \\
\text { duration indicator }\end{array}$ & $\begin{array}{l}\text { Annual number of days with at least } 6 \text { consecutive } \\
\text { days when Tmax }>90 \text { th percentile }\end{array}$ & Days per year \\
\hline & Frequency & & \\
\hline TX10p & Cool days & Number of days when Tmax $<10$ th percentile & Days per season \\
\hline TN10p & Cool nights & Number of days when Tmin $<10$ th percentile & Days per season \\
\hline TX90p & Warm days & Number of days when Tmax $>90$ th percentile & Days per season \\
\hline \multirow[t]{2}{*}{ TN90p } & Warm nights & Number of days when Tmin $>90$ th percentile & Days per season \\
\hline & B. Rainfall & & \\
\hline RX1day & & Maximum daily rainfall & $\mathrm{mm}$ \\
\hline RX5day & & $\begin{array}{l}\text { Maximum rainfall occurring over a } 5 \text { day } \\
\text { consecutive period }\end{array}$ & $\mathrm{mm}$ \\
\hline
\end{tabular}

assumptions about the distribution of the data. This method was used by Deo et al. (2009) and Avila et al. (2012) in studies of climate extreme indices. Grid points with statistically significant differences are shown in colour in the bubble maps with red indicating warmer and drier and blue indicating cooler and wetter climates. For each of the regions of interest (Northern Hemisphere, $0-70^{\circ} \mathrm{N}, 180^{\circ} \mathrm{W}-180^{\circ} \mathrm{E}$; North America, $30-55^{\circ} \mathrm{N}, 78-123^{\circ} \mathrm{W}$; Eurasia, $40-65^{\circ} \mathrm{N}$, $0-90^{\circ} \mathrm{E}$; and South East Asia, $11-40^{\circ} \mathrm{N}, 73-135^{\circ} \mathrm{E}$ ) the percentage of significant grid points were also calculated.

\section{Results}

\subsection{Mean impact of LULCC at different levels of atmospheric carbon dioxide}

We begin with a brief discussion of how LULCC and the change in $\mathrm{CO}_{2}$ affect the mean temperature and rainfall because these changes help explain how extremes change. Figure 2 shows the impact of LULCC on the mean temperature in March-April-May (MAM) and June-July-August (JJA) at 280 ppmv and 375 ppmv. To act as a reference to the impact of LULCC, the response to solely an increase in $\mathrm{CO}_{2}$ on tem- perature is also shown. In terms of the mean response, in MAM and JJA, LULCC tends to cool the Northern Hemisphere mid-latitudes but the response is varied, ranging from a strong response in ARPEGE and ECEarth to a weaker response in ECHAM5 and a warming in IPSL in JJA. The explanation for these different responses in the mean temperature was provided by de Noblet-Ducoudré et al. (2012) and is related to both the intensity of land cover change (note, Fig. 1 shows ECHAM5 to implement change somewhat less intensely than ARPEGE or ECEarth), and how crops are parameterized in the model. There are three conclusions from Fig. 2. First, the impact of LULCC is broadly similar at both $280 \mathrm{ppmv}$ and $375 \mathrm{ppmv}$ and in both cases LULCC causes mid-latitude cooling (except for the warming in IPSL during JJA), reaching $2{ }^{\circ} \mathrm{C}$ in some regions. Second, the increase in $\mathrm{CO}_{2}$ from $280 \mathrm{ppmv}$ to $375 \mathrm{ppmv}$ causes large-scale warming of mainly $0.4-1.5^{\circ} \mathrm{C}$. Third, the increase in $\mathrm{CO}_{2}$ leads to warming almost everywhere, while LULCC tends to have a more regionalized impact. An interesting result in JJA is that the model with the largest global warming due to the increase in $\mathrm{CO}_{2}$ (ECHAM5) is the model with the weakest sensitivity to LULCC. While this suggests that a model's sensitivity to a land cover perturbation is not directly proportional to the 

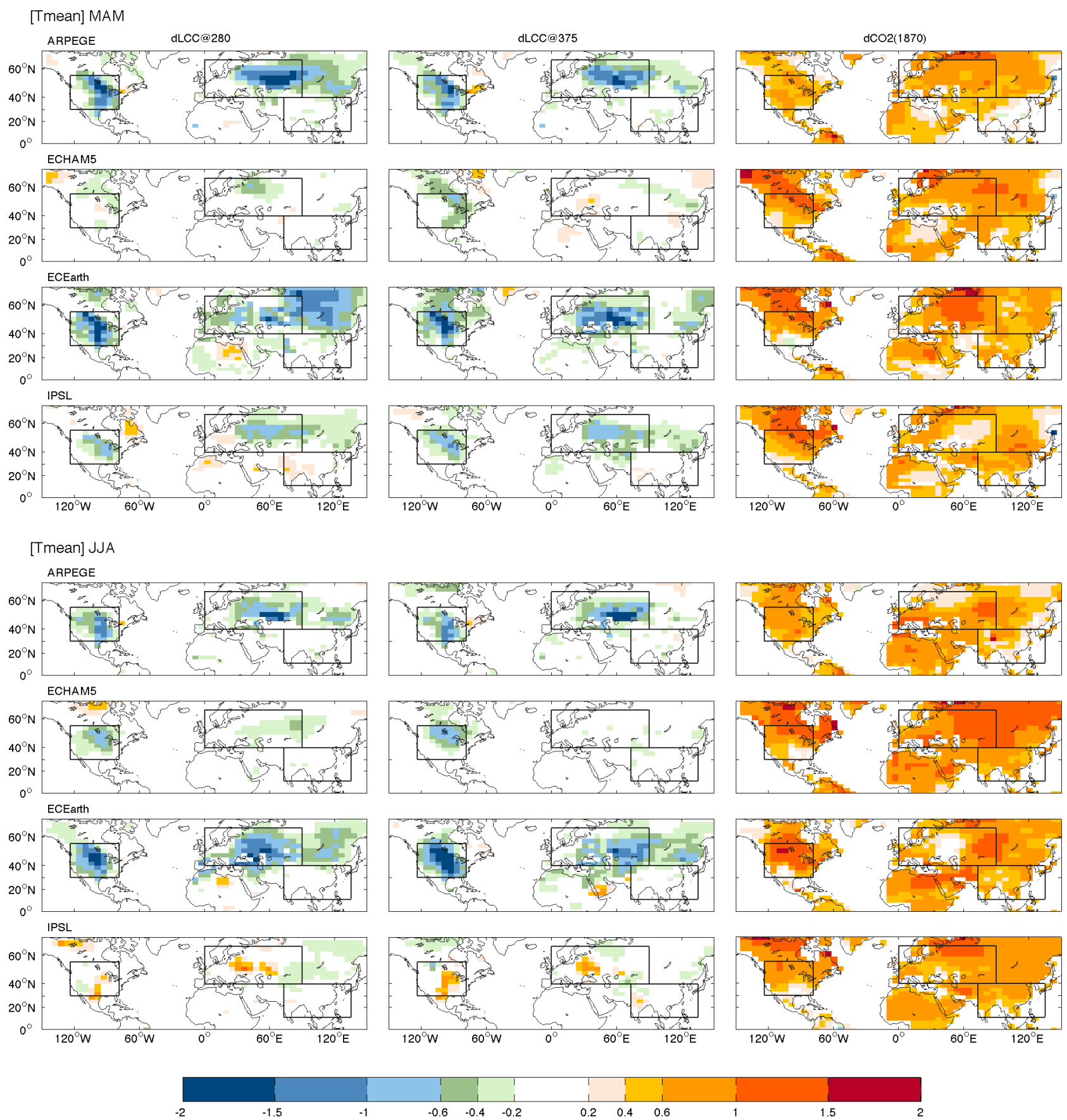

Fig. 2. Change in the mean surface air temperature $\left({ }^{\circ} \mathrm{C}\right)$ in March-April-May (MAM) and June-July-August (MAM) for the four models. The left column is the impact on the mean surface air temperature of LULCC at a $\mathrm{CO}_{2}$ concentration of $280 \mathrm{ppmv}$ (PIv-PI). The middle column is the impact of LULCC at a $\mathrm{CO}_{2}$ concentration of $375 \mathrm{ppmv}$ (PD-PDv). The right column shows the impact of the increase in $\mathrm{CO}_{2}$ alone using land cover reflecting 1870 conditions (PDv-PI).

model sensitivity to the $\mathrm{CO}_{2}$ forcing, this is complicated by the intensity of LULCC, which varies between the models.

In terms of precipitation, Fig. 3 shows the mean model response to LULCC and to the increase in $\mathrm{CO}_{2}$ from 280 ppmv to 375 ppmv. The impact of LULCC on precipitation is generally weak in all models at both $280 \mathrm{ppmv}$ and 375 ppmv. However, there are similarities between the impacts of LULCC at the two $\mathrm{CO}_{2}$ levels, particularly in JJA. At both 280 ppmv and 375 ppmv, ARPEGE simulates a small increase of summer precipitation over Eurasia and a decrease over North America; ECHAM5 simulates a small increase over parts of North America; ECEarth simulates 

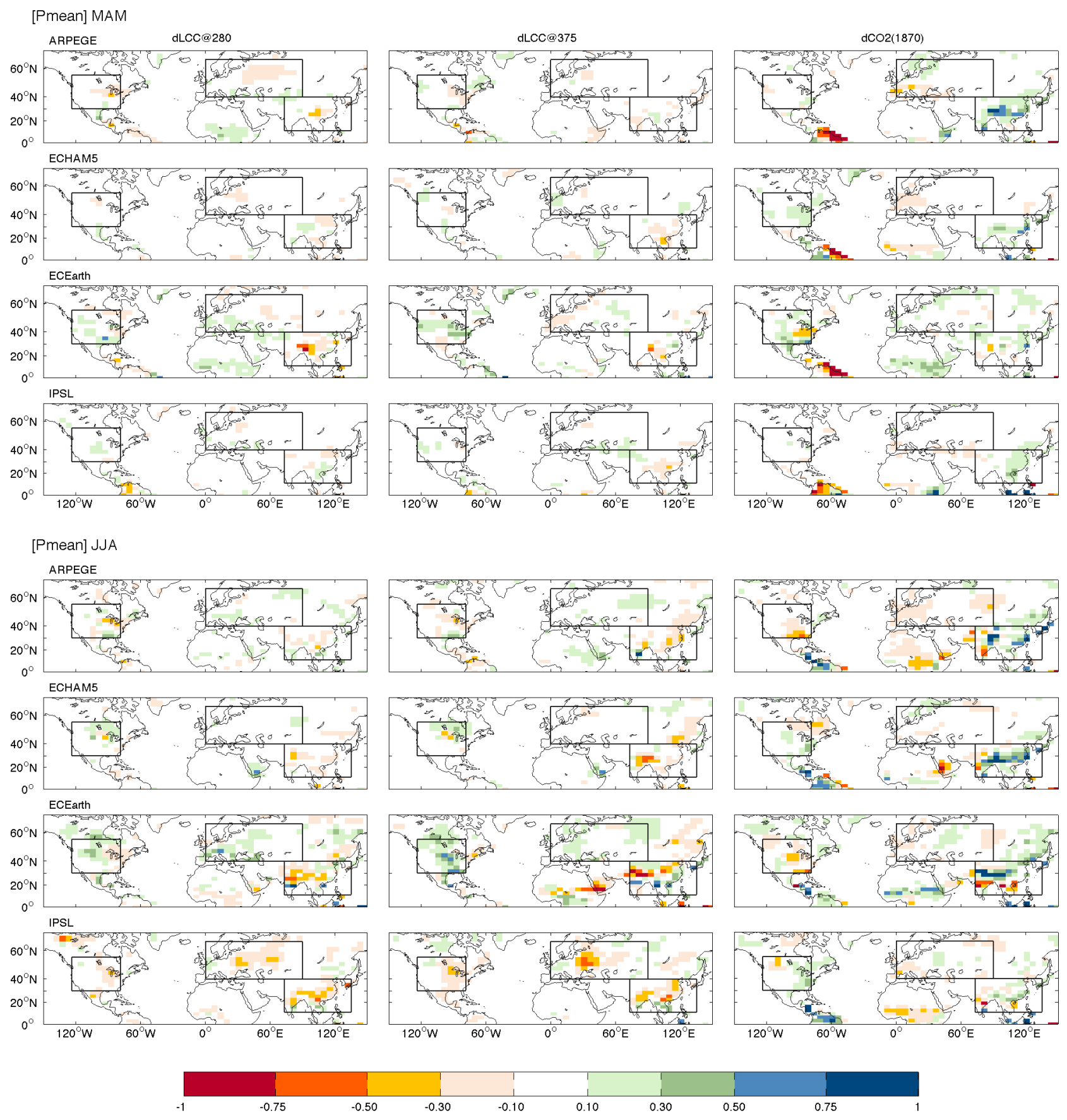

Fig. 3. As Fig. 2 but for mean precipitation $\left(\mathrm{mm} \mathrm{day}^{-1}\right)$.

increase over North America and Eurasia and IPSL simulates decreases over North America and Eurasia. If LULCC did not affect rainfall, then the individual regions affected by rainfall changes in Fig. 3 would likely vary randomly between the results at 280 ppmv and 375 ppmv. Since there are similarities in the regional pattern of change in rainfall due to LULCC at both $\mathrm{CO}_{2}$ levels, it is likely that while the models disagree on the sign of the impact of LULCC on precipita- tion, internally each model is affected by LULCC in a consistent way.

The apparent decreases in rainfall over S.E. Asia simulated by all models in JJA due to LULCC at both 280 ppmv and 375 ppmv are intriguing (Fig. 3). The response is weaker in ARPEGE and ECHAM5, which is expected because the models also simulate a weaker response to LULCC elsewhere (in part due to a smaller intensity of LULCC in 
ECHAM5, see Fig. 1). The decline in mean rainfall covers a large region of S.E. Asia, particularly in ECEarth and IPSL, and occurs at both 280 and 375 ppmv. Similarly, the increases in precipitation over S.E. Asia in both MAM and JJA due to the increase in $\mathrm{CO}_{2}$ and associated changes in sea surface temperatures are also consistent between the models. In general, the pattern of the $\mathrm{CO}_{2}$-induced precipitation changes agree much better between the models than for LULCCinduced changes, pointing at more complex processes and feedbacks linking land surface parameterization and rainfall, than between changes in GHG concentrations and rainfall.

Overall, LULCC over S.E. Asia appears to decrease rainfall in all models, which is the opposite signal due to the increase in $\mathrm{CO}_{2}$, which leads to increased precipitation in all models. Our results suggest that simulations of the impact of increasing $\mathrm{CO}_{2}$ over S.E. Asia that omit the impacts of LULCC will lead to erroneous conclusions on the precipitation response when discussing anthropogenic-induced climate change. However, the magnitude of the impact of LULCC on rainfall $\left( \pm 1 \mathrm{~mm} \mathrm{day}^{-1}\right)$ is not particularly large and the $\mathrm{CO}_{2}$ change included here is not representative of mid- to late-21st century levels. While LULCC may well continue to be intensive in S.E. Asia, increases in $\mathrm{CO}_{2}$ will likely remain the dominant regional forcing on rainfall throughout the 21 st century.

\subsection{Impact of LULCC on temperature intensity extremes}

The impact of LULCC on TXX (warmest seasonal daily maximum temperature) is shown in Fig. 4 for MAM and JJA. In MAM, a reduction in TXx is simulated due to LULCC by models over some parts of North America but the scale of the reduction varies in spatial scale from most of North America (ECEarth) to just a few grid points (ECHAM5). ECHAM5 simulates a region of increase in TXx coincident with the most northern region of LULCC (Fig. 1) over North America. Results are generally consistent over North America between the models at both $280 \mathrm{ppmv}$ and $375 \mathrm{ppmv}$. Over Eurasia, ECEarth simulates a larger region of decreases in TXx in comparison to the other models and ECHAM5 simulates increases in TXx at 375 ppmv. The impact of the increase in $\mathrm{CO}_{2}$ on TXx is generally more widespread and is almost always an increase. Thus, in most models the $\mathrm{CO}_{2}$ induced increase in TXx is suppressed by LULCC. In the case of ECEarth and IPSL, the decrease in TXx due to LULCC in MAM would dominate the change due to an increase in $\mathrm{CO}_{2}$, reversing the sign of the change over Eurasia and over large parts of North America. Results are similar for JJA with the exception of IPSL, which simulates an increase in TXx, amplifying the impact of increased $\mathrm{CO}_{2}$ while the other models simulate a decrease in TXx locally, suppressing the response to $\mathrm{CO}_{2}$. The increase in IPSL is associated with the mean temperature change (Fig. 2). In both MAM and JJA, the scale of impact of LULCC on TXx is of a sim- ilar magnitude, but much less widespread than the impact of increasing $\mathrm{CO}_{2}$. Note that there are no changes in TXx remote from regions of LULCC that are consistent between the models.

Comparing Fig. 2 with Fig. 4 suggests some relationship between the change in the mean surface air temperature and the change in TXx for LULCC in both MAM and JJA. However, while the sign of the change in TXx accurately reflects the sign of the change in the mean, and to some degree the magnitude of the change in the mean is proportional to the change in the magnitude of TXx, this is model-dependent. The relationship between the change in the mean and the change in TXx is relatively strong in ECEarth for all regions of significant LULCC. In contrast, the relationship is weaker for ARPEGE but there is still a tendency for a large increase in the mean to be reflected by a larger increase in TXx. There is little relationship between the change in the mean and the change in TXx in ECHAM5 and IPSL. Boisier et al. (2012) explored the role of the total turbulent energy flux (the sum of the sensible and latent heat fluxes) in explaining the impact of LULCC. We also explored whether the change in the total turbulent energy flux could be correlated with the change in TXx but could find no relationship.

A similar pattern of results is shown in Fig. 5 for $\mathrm{TNn}$ (coldest seasonal daily minimum temperature). LULCC reduces TNn in MAM and in JJA by similar amounts at 280 ppmv and 375 ppmv and in both cases this offsets increases in TNn due to the increase in $\mathrm{CO}_{2}$. In MAM and JJA there is quite a large response in TNn to LULCC in ARPEGE and ECEarth and a weak response in ECHAM5 and IPSL. The relationship between the change in the mean temperature and TNn is very similar to that discussed for TXx. As with TXx, there are no changes in TNn remote from regions of LULCC that are consistent between the models.

\subsection{Impact of LULCC on temperature frequency extremes}

The impact of LULCC on TX90p (warm days, defined as the number of days when Tmax >90th percentile) shows decreases in this measure over North America and Eurasia in MAM in ARPEGE, ECEarth and IPSL, but little change in ECHAM5 (Fig. 6). To allow a comparison of the different forcing effects, all percentile exceedances in Figure 6 relate to the 10th/90th percentile of daily Tmax calculated for the PI simulation. There are strong overall similarities between the impact at $280 \mathrm{ppmv}$ and $375 \mathrm{ppmv}$. As with TXx and TNn, LULCC tends to locally offset the impact of increasing $\mathrm{CO}_{2}$. Again, in common with the changes in the mean and TXx, IPSL simulates an increase over parts of Europe in JJA in contrast to the decrease simulated by the other models. Thus, in JJA, LULCC locally offsets the impact of increased $\mathrm{CO}_{2}$ on TX90p in ARPEGE, ECHAM5 and ECEarth but amplifies it in IPSL. Consistent with earlier results, there are no 

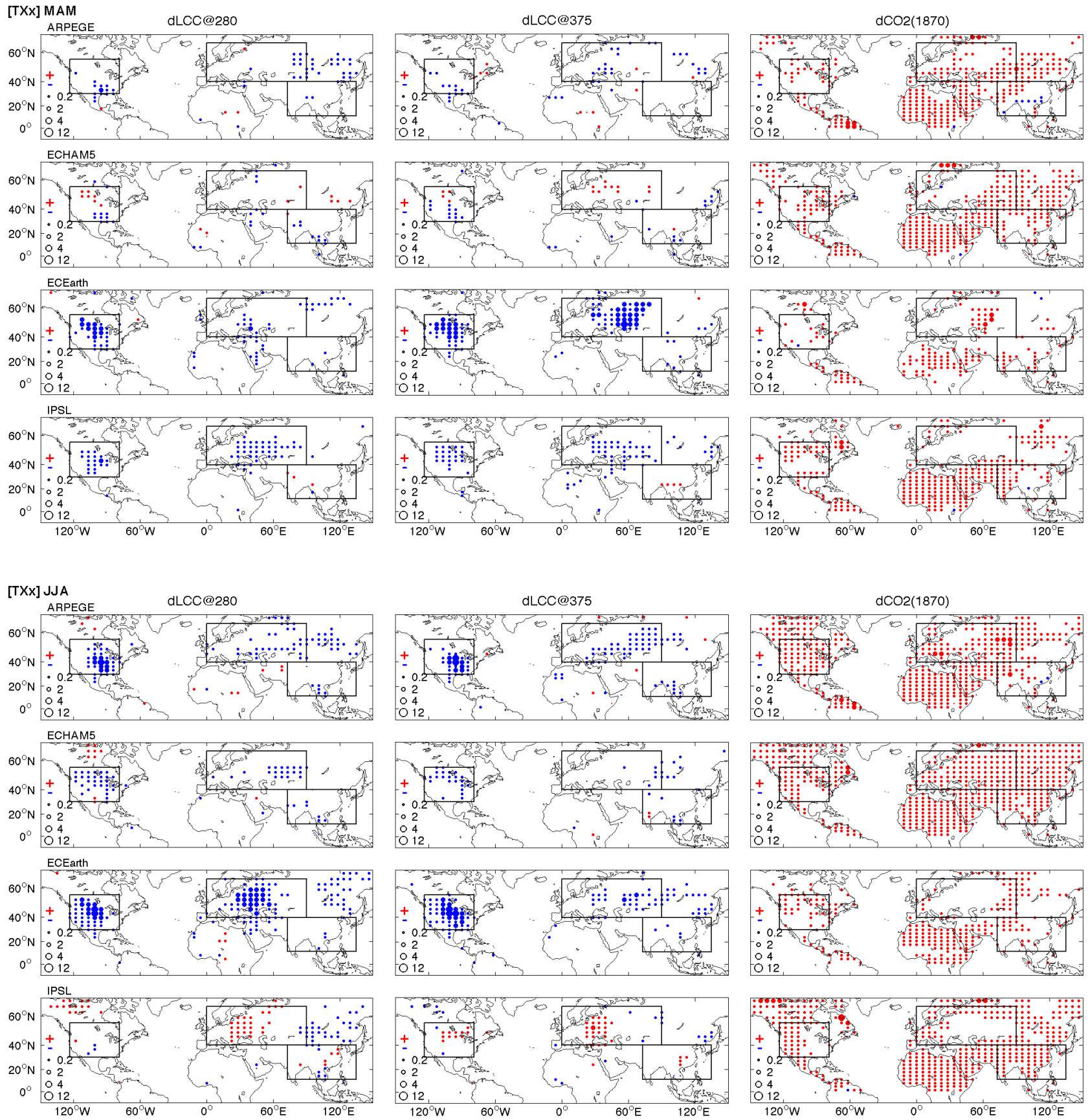

Fig. 4. As Fig. 2 but for the warmest seasonal daily maximum temperature $\left(\mathrm{TXx},{ }^{\circ} \mathrm{C}\right)$. Only the grid points that are statistically significant at the $95 \%$ level using the two-tailed Kolmogorov-Smirnov test are shown (red for warming and blue for cooling). The magnitude of the change is indicated by the size of the circles.

changes in TX90p remote from regions of LULCC that are consistent between the models.

Results are very similar for TX10p (cool days, defined as the number of days per season when Tmax $<10$ th percentile from the PI simulation), for TN10p (cool nights, defined as the number of days per season when Tmin $<10$ th percentile from the PI simulation) and for TN90p (warm nights, de- fined as the number of days per season when Tmin $>90$ th percentile). In each case, the overall impact of LULCC is a cooling (increased TN10p and TX10p, decreased TN90p) of these measures in both North America and Eurasia, offsetting the $\mathrm{CO}_{2}$-induced warming. In each case, IPSL is an exception in JJA, where LULCC suppresses the $\mathrm{CO}_{2}$ induced decreases (TN10p, TX10p) and increases (TN90p) 

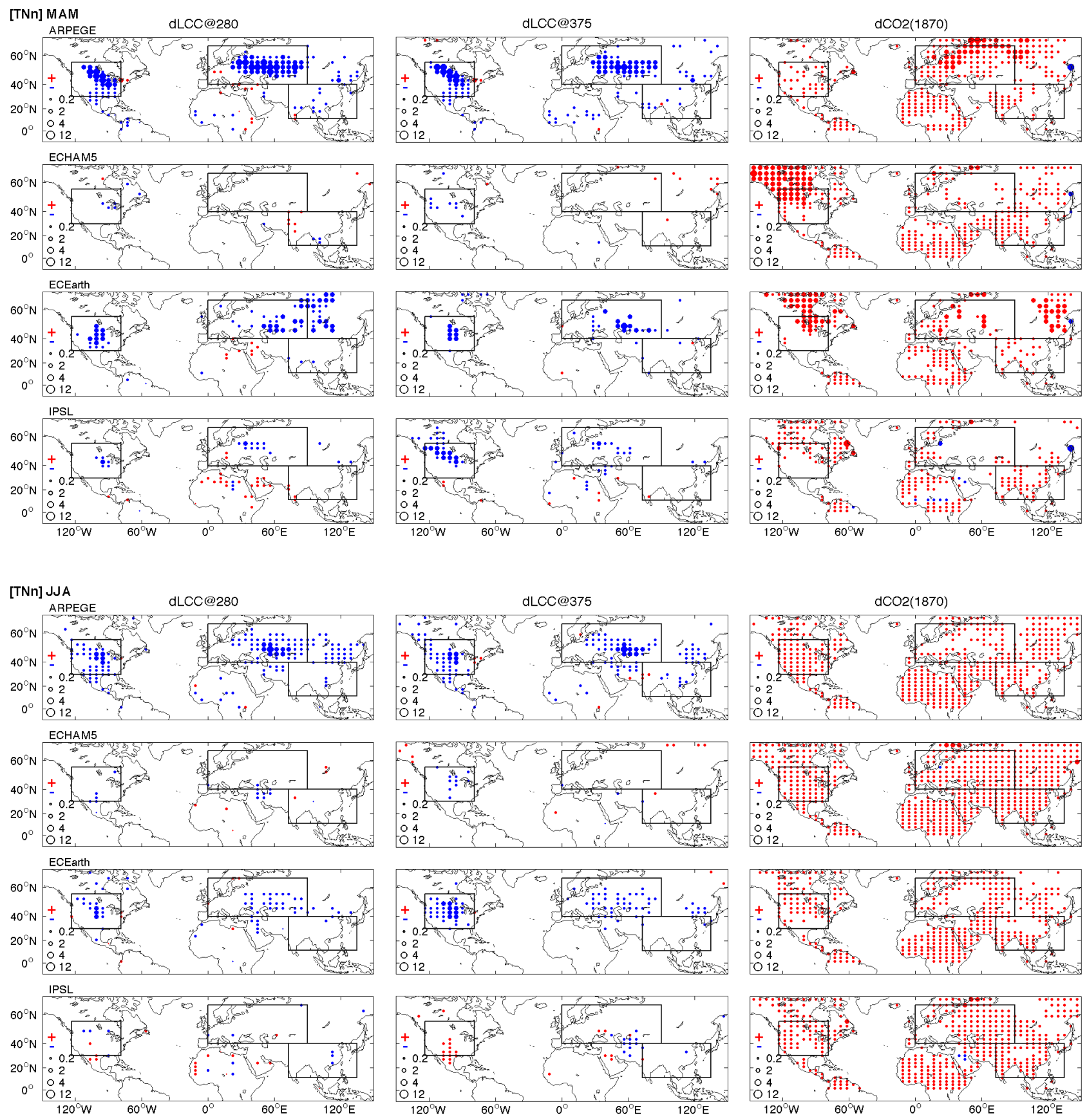

Fig. 5. As Fig. 4 but for the coldest seasonal daily minimum temperature (TNn, $\left.{ }^{\circ} \mathrm{C}\right)$.

respectively. In all cases, there are no changes remote from regions of LULCC that are consistent between the models.

\subsection{Impact of LULCC on temperature duration extremes}

The impact of LULCC on WSDI (warm spell duration) is shown in Fig. 7. ARPEGE simulates a decrease in WSDI over Eurasia, IPSL simulates an increase, ECHAM5 and ECEarth simulate negligible change at $280 \mathrm{ppmv}$. There is a strong amplification of the impact of LULCC at $375 \mathrm{ppmv}$ in ARPEGE over Eurasia and in ECEarth over North America. Both of these amplifications would largely offset the $\mathrm{CO}_{2}$ induced changes.

There is a very strong response to LULCC in the cold spell duration (CSDI, Fig. 8) in ARPEGE and ECEarth. Both models simulate a large increase in days with at least 6 consecutive days when Tmin $<10$ th percentile at both 280 and 375 ppmv. These changes are large relative to the impact of 

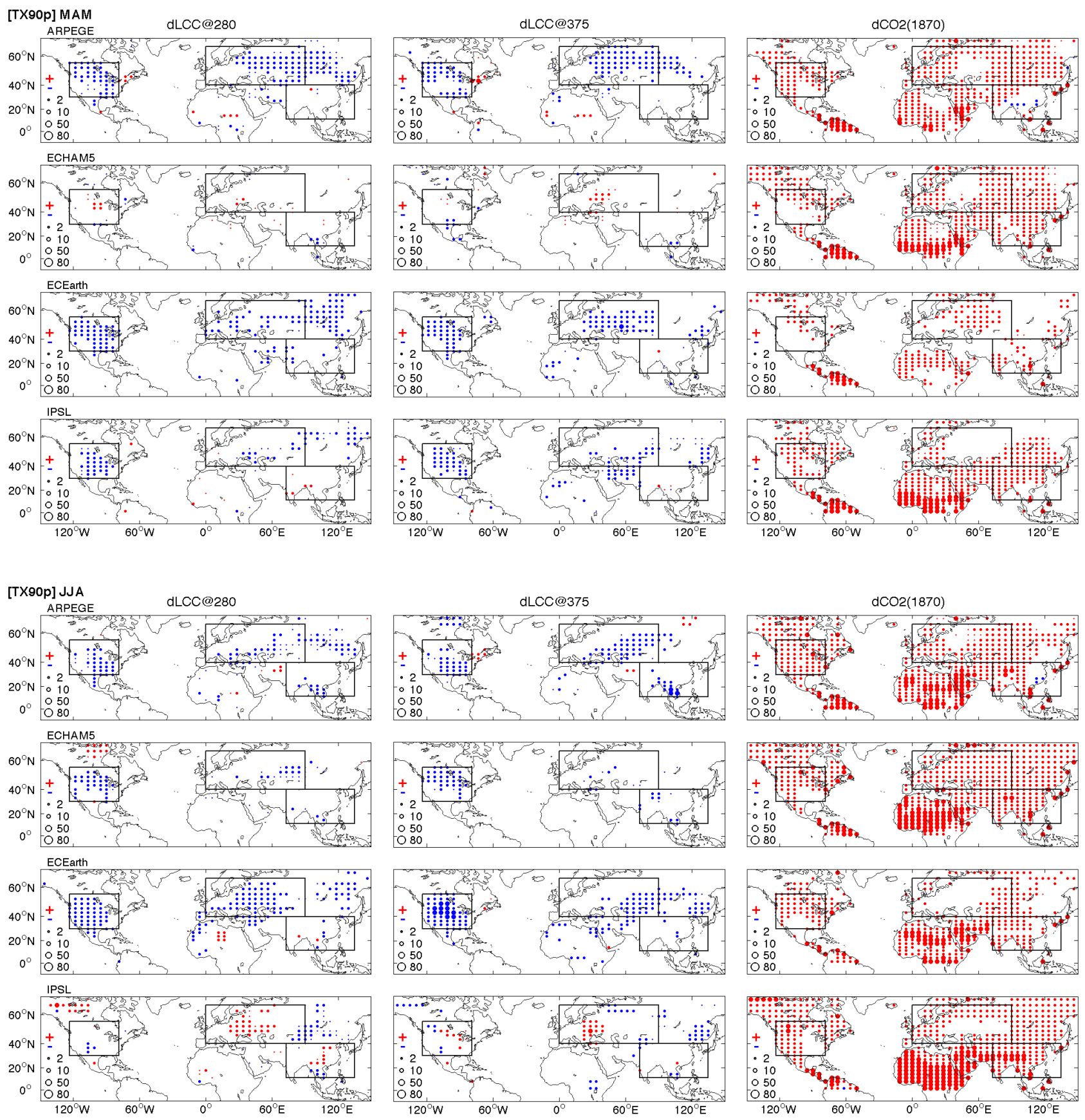

Fig. 6. As Fig. 4 but for the number of days when Tmax $>90$ th percentile relative to the PI simulation (TX90p, days/season).

the increased $\mathrm{CO}_{2}$ and oppose the sign of the net impact from $\mathrm{CO}_{2}$ alone. CSDI in ECHAM5 is consistently insensitive to LULCC, which may in part be due to the lower intensity of the LULCC (Fig. 1) although the relationship between the scale of LULCC and its impact on indices such as CSDI are unknown. Changes in CSDI are $\mathrm{CO}_{2}$ concentration-specific and the impact of LULCC declines under higher $\mathrm{CO}_{2}$ in most models. This decrease is most clear in ECEarth but is also apparent in ARPEGE (North America and S.E. Asia), and IPSL (a lot of significant points disappear under higher $\mathrm{CO}_{2}$ ). This is likely due to $\mathrm{CO}_{2}$-induced warming and a loss of snow cover that reduces the sensitivity of the climate to LULCC (Pitman et al., 2011). Again, consistent with earlier results there are no changes in either CSDI or WSDI remote from regions of LULCC that are consistent between the models. 

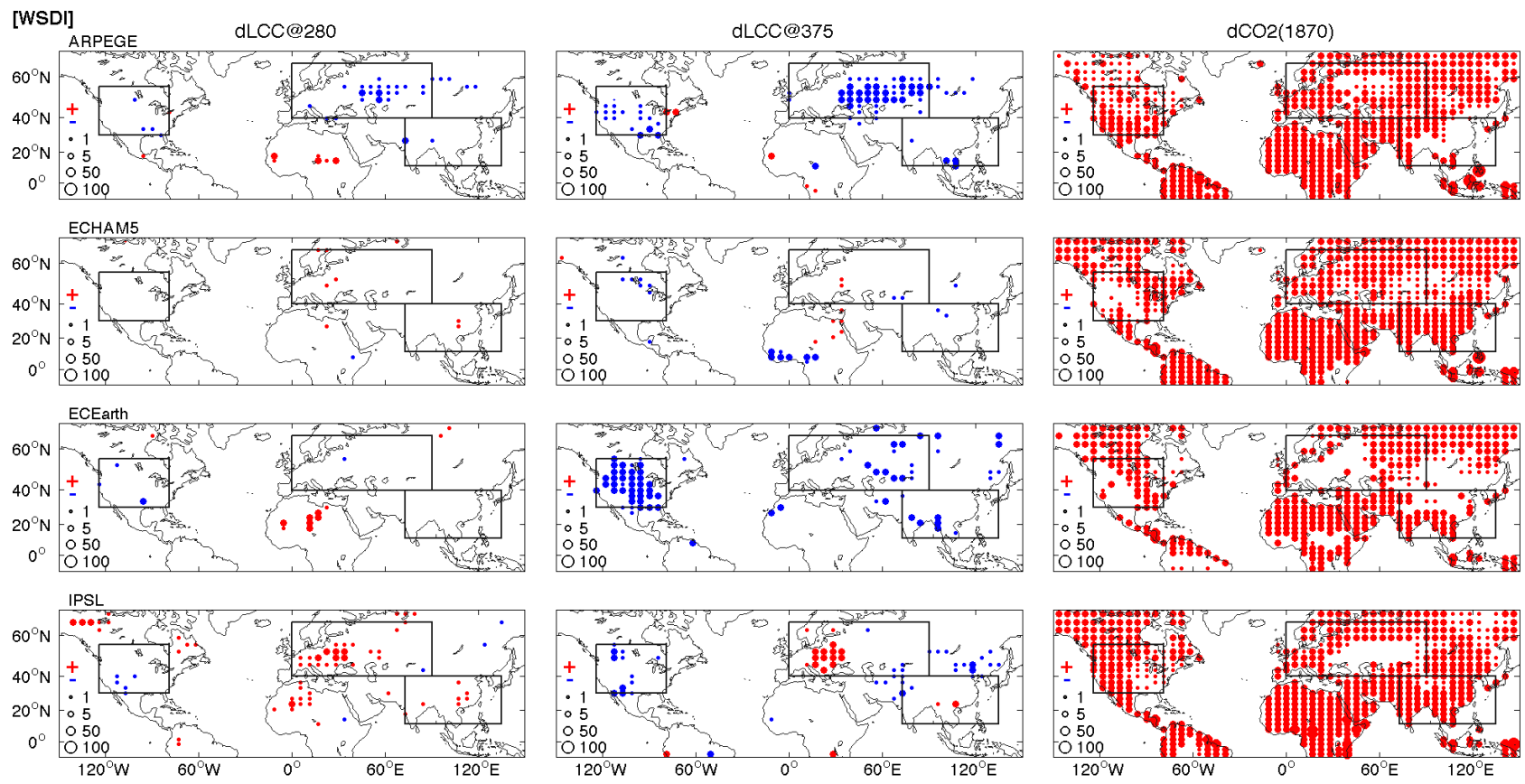

Fig. 7. As Fig. 4 but for the warm spell duration index (WSDI, days $\mathrm{yr}^{-1}$ ).
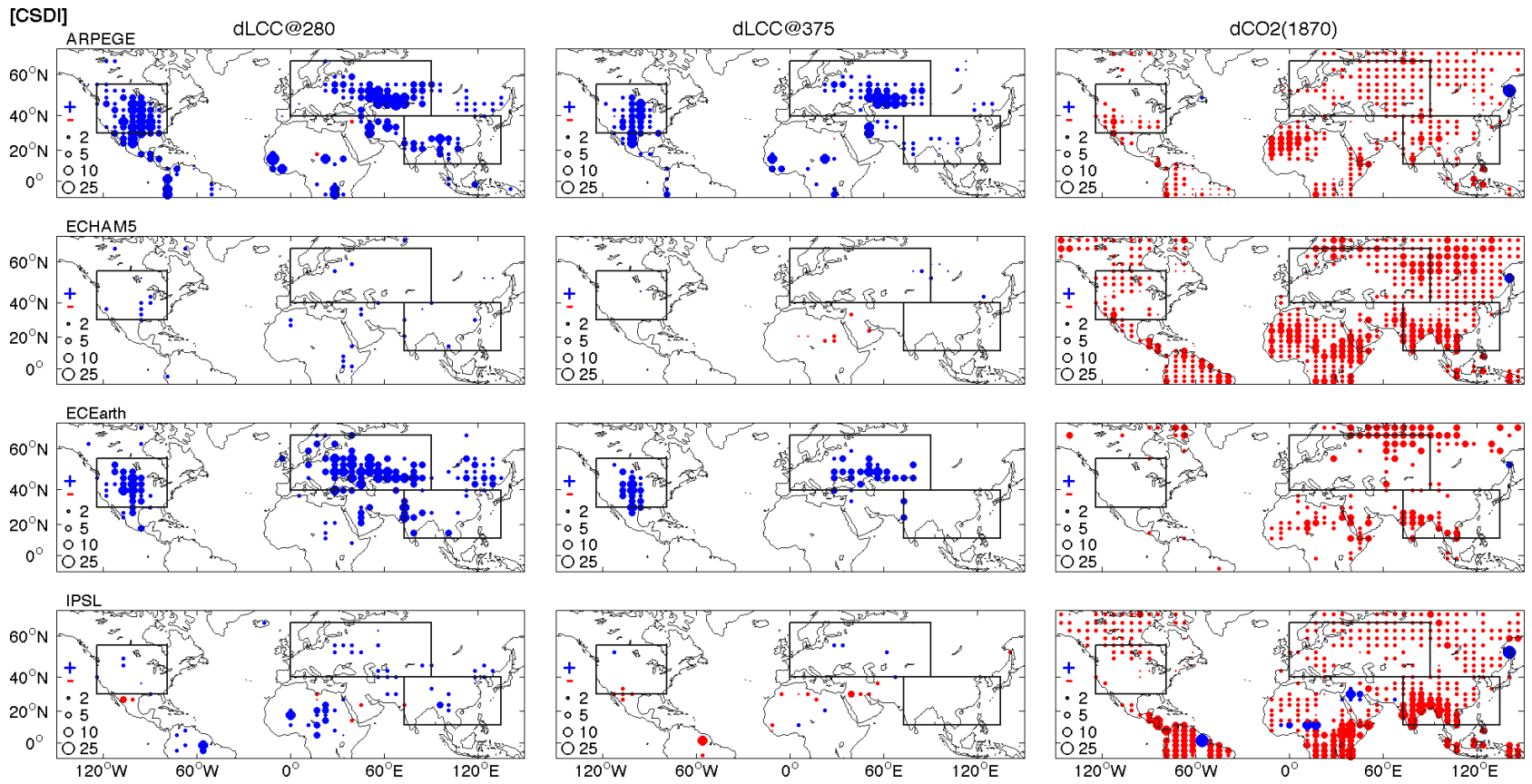

Fig. 8. As Fig. 4 but for the cold spell duration index (CSDI, days $\mathrm{yr}^{-1}$ ). Note that for this index, blue indicates an increase in the number of cold days and red indicates a decrease in the number of cold days.

\subsection{Impact of LULCC on rainfall extremes}

We include results from the four models for one rainfall index (RX5day, the maximum rainfall occurring over a 5-day period). Results from RX1day, the maximum rainfall occur- ring over a 1-day period were similar in geographic extent and of order $20 \%$ of the magnitude shown for RX5day.

The impact of LULCC on RX5day is highly variable. Figure 9 shows both increases and decreases in RX5day for MAM and JJA. There is a co-location of decreases in RX5day and LULCC over North America and Eurasia in 

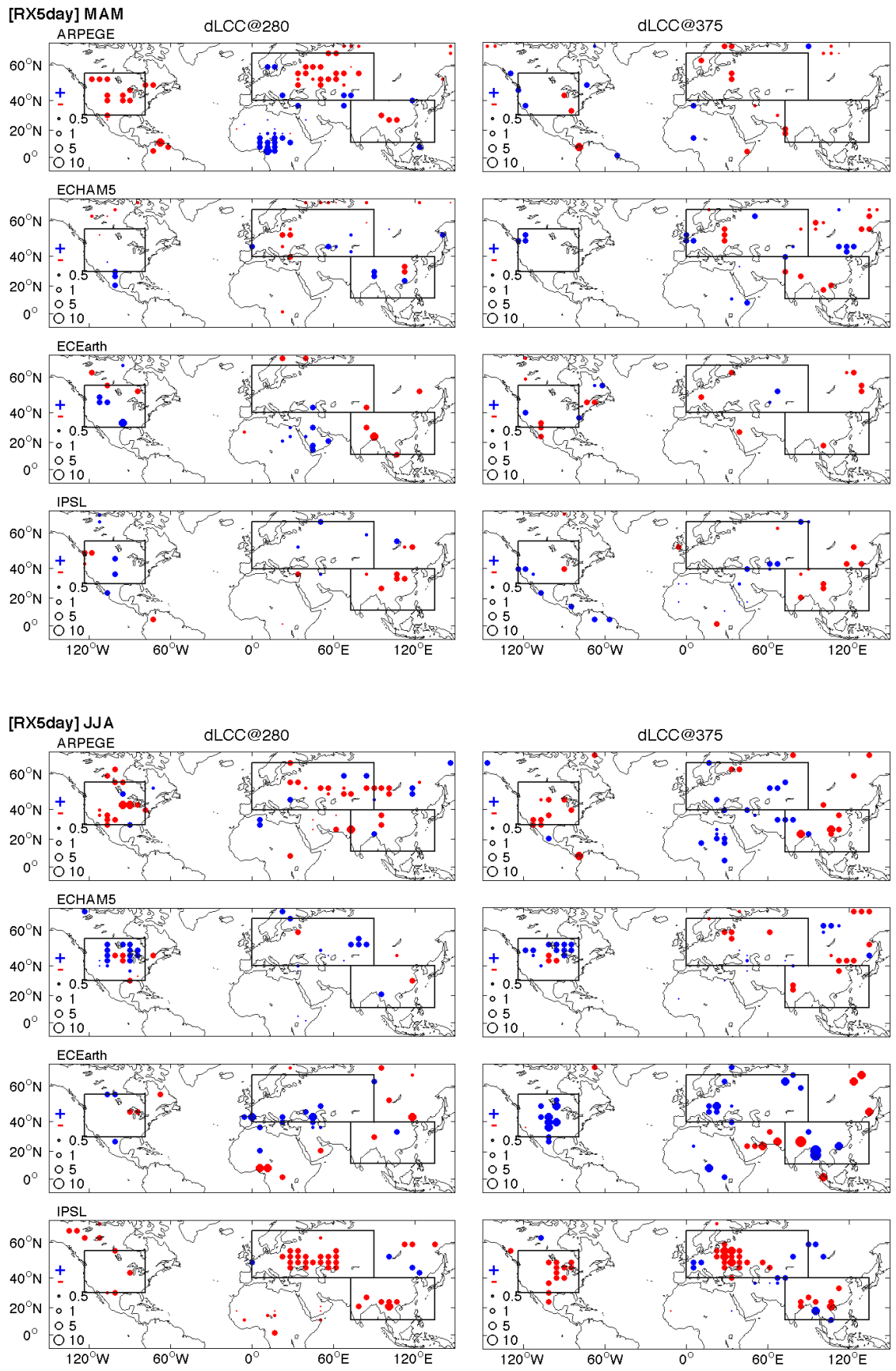
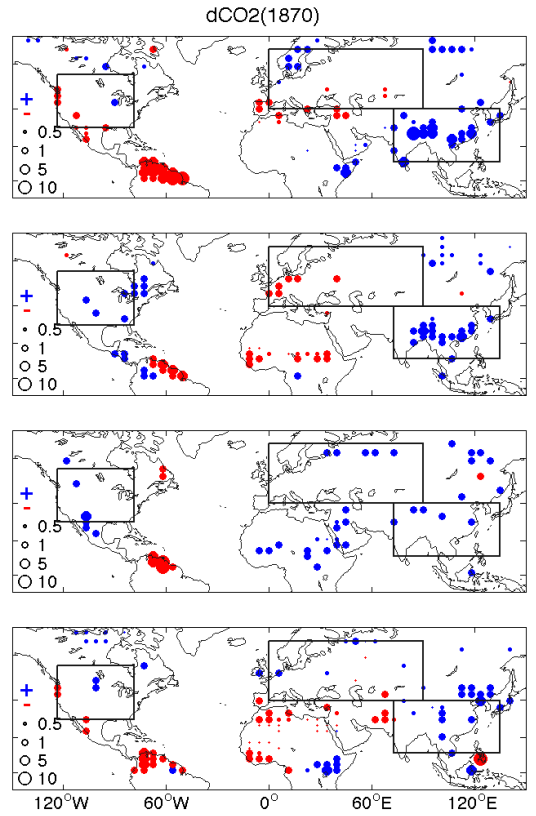

Fig. 9. As Fig. 4 but for the maximum rainfall occurring over a 5 day consecutive period (RX5day, mm). Note that for this index, blue indicates increased rainfall and red indicates decreased rainfall.

both seasons in ARPEGE at 280 ppmv, but not at 375 ppmv. RX5day increases and decreases over North America in JJA in ECHAM5 at both $\mathrm{CO}_{2}$ levels. There are increases in RX5day at $375 \mathrm{ppmv}$ in JJA in ECEarth, but not at 280 ppmv. Finally, RX5day is reduced in IPSL at both levels of $\mathrm{CO}_{2}$ in JJA.

One would expect the largest impact of LULCC on rainfall extremes to be during summer coincident with high net radi- ation, surface evaporation and convection. The JJA results from ARPEGE and IPSL suggest that rainfall extremes in these models do respond to LULCC and both models show a decrease of extreme precipitation at many grid boxes affected by LULCC. However, even in JJA there are major inconsistencies in how ARPEGE and IPSL respond to LULCC at the two $\mathrm{CO}_{2}$ levels. Further, ECHAM5 and ECEarth do not hint at a large change in RX5day. It is therefore very 
difficult to conclude anything in terms of extreme rainfall from our results.

We explored the relationship between changes in RX5day and mean rainfall, and between RX5day and the total turbulent energy flux $\left(Q_{\mathrm{t}}\right)$ for each model (Table 4$)$. We found a reasonably strong and consistent relationship between changes in mean rainfall and changes in RX5day in ECEarth in all three regions of LULCC. This relationship was weaker for ARPEGE and non-existent for IPSL and ECHAM5. A similar result is shown in Table 4 for the relationship between RX5day and the total turbulent energy flux. ECEarth, and to a weaker degree ARPEGE, show a correlation between these quantities, but there is none for IPSL or ECHAM5.

Finally, the scale of the simulated change in RX5day is worthy of note. The largest change in RX5day is of order $2 \mathrm{~mm} \mathrm{day}^{-1}$ in the 5-day rainfall total on the seasonal timescale (Fig. 9). In the four models used here, even if LULCC does perturb rainfall extremes, the scale of the change is very small relative to the size of the event.

\section{Discussion}

There is a strong consensus that LULCC affects the mean climate of regions that have been transformed by human activity (Pielke et al., 2011). In common with some other processes, such as cloud cover-induced feedbacks on the surface radiation balance (van der Molen et al., 2011), LULCC appears to have a clear zonal signature. This paper examines how LULCC affects four climate models' simulation of temperature and rainfall extremes using a selection of the ETCCDI extreme climate indices. This work builds on earlier analyses of how LULCC affects the mean climate (de Noblet-Ducoudré et al., 2012; Boisier et al., 2012).

Several of our results reflect earlier studies well. Our results suggest broadly similar impacts from LULCC in the temperature and rainfall indices at 280 and 375 ppmv. This increase in $\mathrm{CO}_{2}$ is not representative of future simulations where concentrations might double or triple so we cannot infer the impact of LULCC on the ETCCDI indices in future climate projections. However, at the levels of $\mathrm{CO}_{2}$ reached to date, the regional impact of LULCC on temperature and rainfall appear similar in magnitude to the $\mathrm{CO}_{2}$ effect in regions of intense LULCC. This is useful because the forced change in $\mathrm{CO}_{2}$ and associated SSTs leads effectively to a new simulation by each model. The recognition that the impact of LULCC is similar across these various simulations of a given model helps reinforce the robustness of the impact of LULCC shown here. Our results also agree with earlier studies that the impact of LULCC on the mean temperature and rainfall is generally coincident with regions of intense land cover change. We extend this result to the ETCCDI extreme indices. Since the impacts of LULCC are largely isolated to the regions of intense land cover change, they are geographically isolated in comparison to the impact of increased $\mathrm{CO}_{2}$.
This conclusion does not preclude the existence of remote changes due to LULCC, in particular because we used fixed sea surface temperatures, but in the models explored here there are no changes simulated remote from LULCC that are common to all four models in either the mean or extremes.

In terms of the impact of LULCC on the ETCCDI indices, the cooling in mean temperature due to LULCC, particularly in the mid-latitudes (Fig. 2), is related to reductions in most of the temperature indices including TXx, TNn, and TX90p. The increase in JJA temperatures due to LULCC in IPSL is also related to increases in TXx, TNn, and TX90p. There is not, however, a simple relationship between these extremes indices and the mean change in all models. While the sign of the change in the mean temperature accurately predicts the sign of the change in each extreme in all four models, it is only ECEarth where the magnitude of the change in the mean predicts the magnitude of the change in TXx (and other indices). In terms of rainfall, there is little correlation between the change in mean rainfall and RX5day, apart from a weak correlation in ECEarth. However, in contrast to earlier LUCID results (Pitman et al., 2009) there are suggestive changes in rainfall resulting from LULCC. This was shown, in particular, for S.E. Asia but there are some consistent impacts from LULCC in other regions.

To explore the impact of LULCC at $280 \mathrm{ppmv}$ and 375 ppmv relative to the increase in $\mathrm{CO}_{2}$, the field significance (see Sect. 2.3) of the changes in each index was derived. The results, shown in Table 5, are expressed as a percentage of grid points that underwent statistically significant changes. The increase in $\mathrm{CO}_{2}$ from $280 \mathrm{ppmv}$ to $375 \mathrm{ppmv}$ led to statistically significant changes in all temperature indices in all models in both MAM and JJA (Table 5). The number of statistically significant points varied by region, by model, and by season but there is clearly a strong and coherent change in the ETCCDI temperature indices due to the increase in $\mathrm{CO}_{2}$. In contrast, the rainfall indices change in a smaller percentage of grid points such that in ECEarth and ECHAM5 no statistically significant changes in the rainfall indices occur due to the increase in $\mathrm{CO}_{2}$ in some regions. In terms of LULCC's impact on the ETCCDI indices, the percentage of points showing a field-significant change is smaller than the impact due to increased $\mathrm{CO}_{2}$, but the impact of LULCC is not negligible. One would expect a smaller impact because while increased $\mathrm{CO}_{2}$ affects every grid point within every region, there are grid points within each region where there is no, or only a very weak land cover perturbation. Despite this contrast between the scale of perturbation, in ARPEGE, ECEarth and to a smaller degree IPSL, 20$40 \%$ of grid points undergo statistically significant changes in the temperature indices in both MAM and JJA following LULCC. ECHAM5, which demonstrated a relatively high sensitivity to the change in $\mathrm{CO}_{2}$, is the least sensitive to LULCC with only the eastern region of the US experiencing more than $40 \%$ of grid points undergoing field significant change. However, this is likely related, at least in part, to 
Table 4. Correlation coefficients between the change in precipitation and the change in RX5day due to LULCC and between the change in RX5day and the change in the sum of the latent and sensible heat fluxes.

\begin{tabular}{|c|c|c|c|c|c|c|}
\hline \multirow[b]{3}{*}{ Model } & \multicolumn{6}{|c|}{ Correlation } \\
\hline & \multicolumn{3}{|c|}{$\Delta \mathrm{P}$ versus $\Delta \mathrm{RX} 5$ day } & \multicolumn{3}{|c|}{$\Delta \mathrm{RX} 5$ day versus $\Delta Q_{\mathrm{t}}$} \\
\hline & Eurasia & North America & S.E. Asia & Eurasia & North America & S.E. Asia \\
\hline ECEarth & 0.73 & 0.72 & 0.75 & 0.35 & 0.30 & 0.42 \\
\hline IPSL & 0.02 & 0.00 & 0.02 & 0.03 & 0.03 & 0.03 \\
\hline ECHAM5 & 0.00 & 0.01 & 0.00 & 0.00 & 0.02 & 0.00 \\
\hline ARPEGE & 0.20 & 0.24 & 0.26 & 0.19 & 0.13 & 0.13 \\
\hline
\end{tabular}

the relatively low intensity of LULCC imposed in the model (Fig. 1). While the percentage of grid points undergoing significant change in the rainfall indices due to LULCC is generally small, in JJA the scale of impact is not much smaller than the impact due to the increase in $\mathrm{CO}_{2}$.

Our results have interesting implications for those analysing the impact of anthropogenic climate change on the ETCCDI indices from climate model simulations that did not include LULCC. As shown by Avila et al. (2012) in the case of some indices, where LULCC triggers regionalscale changes of similar scale to the imposed increase in $\mathrm{CO}_{2}$, interpretation of climate model results should be undertaken very cautiously. Most commonly, in regions of intense LULCC, land cover change would offset the impact of elevated $\mathrm{CO}_{2}$. Surprisingly, this also included partially offsetting a $\mathrm{CO}_{2}$ induced increase in rainfall over S.E. Asia in three of the four models. In some regions, LULCC perturbs the ETCCDI indices to amplify the impact of elevated $\mathrm{CO}_{2}$ (e.g. IPSL for TXx over Eurasia). Clearly, changes in ETCCDI temperature indices cannot be approximated by just changing $\mathrm{CO}_{2}$ in regions of intense LULCC. More seriously, if a model does capture the observed changes in TXx or other indices without representing LULCC, our results suggest a significant risk that the model would be obtaining the right answers for the wrong reasons.

In terms of changes in ETCCDI rainfall indices, we restricted our analysis to RX5day but noted that RX1day showed a similar behaviour with respect of both changes in $\mathrm{CO}_{2}$ and LULCC. Our results cannot confirm or deny a role of large-scale LULCC on rainfall extremes. The results from the four models are too inconsistent to permit a clear relationship to be identified, although an individual model tended to respond to LULCC in terms of mean rainfall consistently at the two levels of $\mathrm{CO}_{2}$. However, there was no consistency between the four models in the direction or magnitude of change in RX5day due to LULCC (Fig. 9). It is likely that the four models we analyse here remain too coarse in terms of spatial resolution or the simulations remain too short to identify a signal, or it may be that LULCC experienced to date does not affect regional-scale rainfall or rainfall extremes.
Finally, we note that due to lack of daily data from some of the models that were used in earlier LUCID experiments, we could only include results from four climate models in this paper. Four models do not provide a good sample of the possible behaviour of climate models in general. Indeed, we have no basis to determine how typical the responses of these models are in comparison to those used in, for example, the Coupled Model Intercomparison Project (CMIP-3 or CMIP-5).

Since LUCID used a consistent experimental design and examined the results across four models we suggest our results are more generally useful than experiments conducted with a single model but a full analysis of the impact of LULCC on regional climate will require a considerably larger effort incorporating irrigation and urbanization and involving a far larger sample of climate models than examined here.

\section{Conclusions}

The impact of LULCC on regional-scale climate averages has been thoroughly studied and a significant impact on the mean temperature should be anticipated over regions of intense LULCC (Pielke et al., 2011). However, the impact of LULCC on climate model-simulated extremes has been less well studied. In this paper we used indices recommended by the CCl/CLIVAR/JCOMM Expert Team on Climate Change Detection and Indices (ETCCDI) based on daily maximum and minimum temperature and daily precipitation. Our experimental design used the Land Use and Climate, IDentification of robust impacts (LUCID) project protocol (Pitman et al., 2009; de Noblet-Ducoudré et al., 2012). We investigated the impact of LULCC on selected ETCCDI indices, using four climate models, contrasting the large-scale impact from LULCC with an increase of atmospheric $\mathrm{CO}_{2}$ from $280 \mathrm{ppmv}$ to $375 \mathrm{ppmv}$. Our LULCC perturbation focused on conversion of forests to crops and pasture and ignores other types of land use change such as urbanization and irrigation that could also strongly affect regional climate (Pielke et al., 2011) but tend to be more localized. The $\mathrm{CO}_{2}$ increase and 
Table 5. Percent of significant grid points in four regions 745 for MAM and JJA for each model used in this paper. The first set of columns of data is for the impact of LULCC at $280 \mathrm{ppmv}$, the second set of columns is for the impact of LULCC at 375 ppmv. The final set of columns is for the impact of the increase in $\mathrm{CO}_{2}$ from $280 \mathrm{ppmv}$ to $375 \mathrm{ppmv}$. Dashes represent points where no grid points were significant.
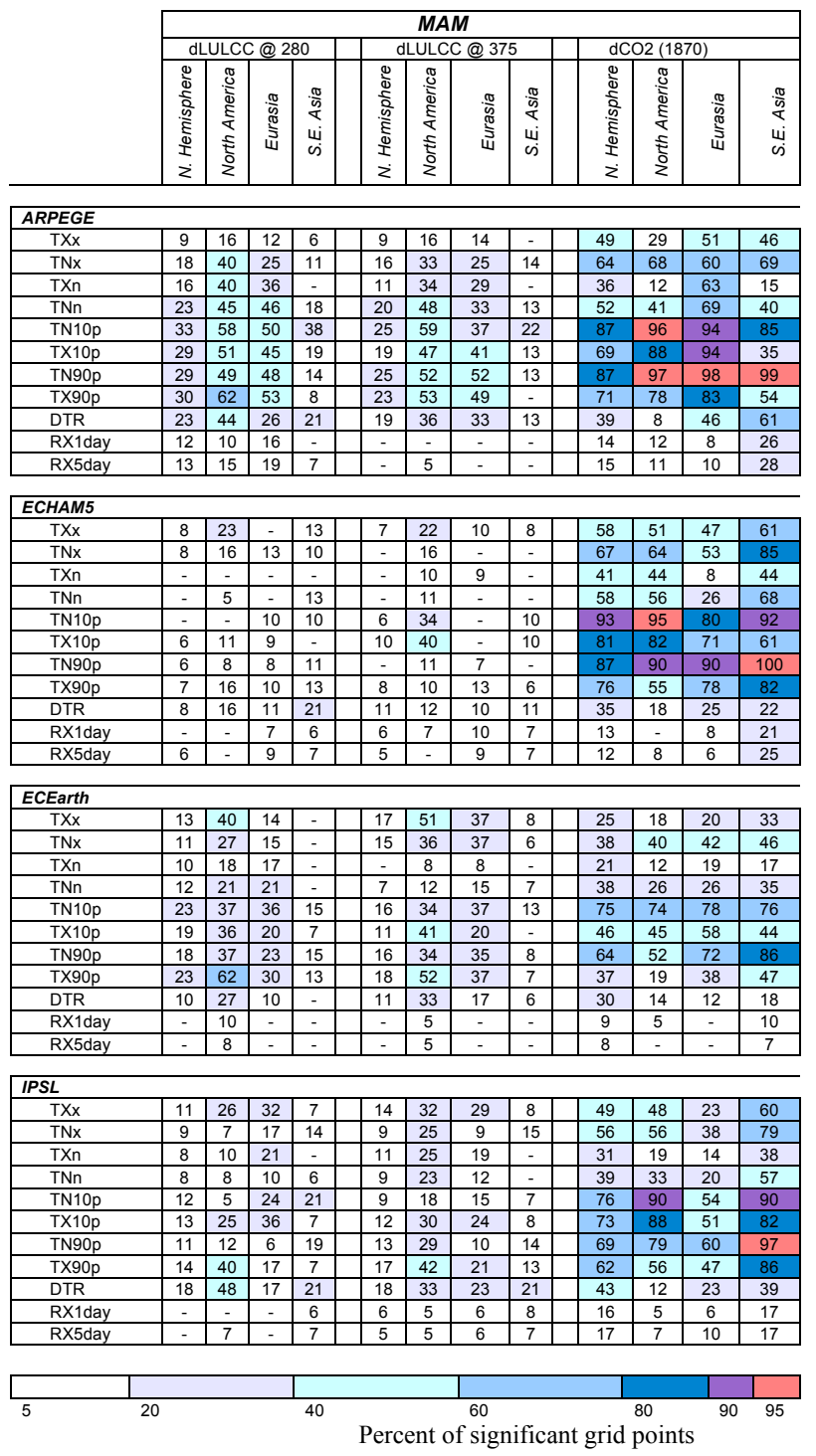

LULCC together reflect significant causes of anthropogenic climate change from the pre-industrial era until today.

In the four climate models examined here, results demonstrate that the impact of the increase in $\mathrm{CO}_{2}$ on the ETC$\mathrm{CDI}$ indices is much more geographically extensive but often of a similar magnitude than the impact of LULCC. However, many of the temperature indices show locally strong and statistically significant responses to LULCC, such that commonly $30-50 \%$ of the continental surfaces of the tropics and Northern and Southern Hemispheres are affected statistically significantly by LULCC. To avoid any risk of misunderstanding, we remind readers that the increase in $\mathrm{CO}_{2}$ imposed here is $280 \mathrm{ppmv}$ to $375 \mathrm{ppmv}$ and not an increase representative of future concentrations. We do not imply that
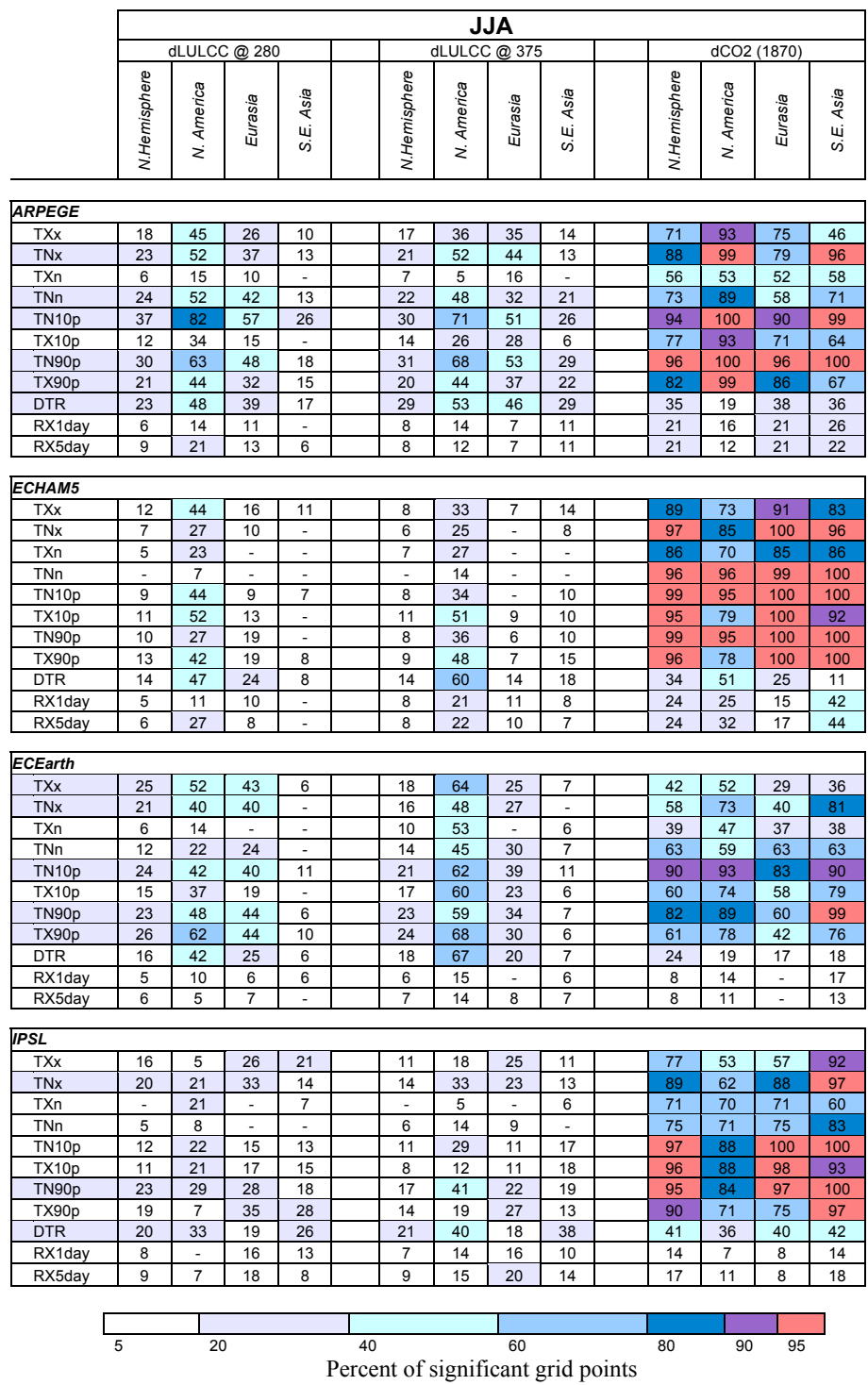

LULCC would likely affect the ETCCDI indices as much as a doubling or tripling of $\mathrm{CO}_{2}$. We also note that our LULCC perturbation omits irrigation and urbanization and therefore likely underestimates the impact of LULCC.

There is a great deal more to be done in associating LULCC with temperature and rainfall extremes. LUCID provided a starting point for this analysis but only four models were available, and these four models contrasted sharply in how they responded to LULCC in terms of simulated extremes. It is not possible to determine, without further experiments, whether these four models represent a large fraction of uncertainty in the role of LULCC in affecting extremes or whether additional models would give contradictory results. To resolve the remaining challenges associated with 
simulating the impacts of LULCC on extremes requires a considerable effort. De Noblet-Ducoudré et al. (2012) argued that land surface modellers should evaluate models using observations where land use change has been imposed in order to better resolve how this change affects the mean climate. Analyses of these types will also help resolve the impact of LULCC on extremes. In addition, experiments with more models to provide a larger sample would be useful, ideally including irrigation and urbanization.

We conclude that, based on our results, in terms of using the ETCCDI indices for climate impacts studies at large spatial scales, LULCC needs to be incorporated only where LULCC has been intensive. These regions of intensive LULCC are, of course, closely correlated with human population density. In some cases, LULCC affects the ETC$\mathrm{CDI}$ indices in the same direction as increasing $\mathrm{CO}_{2}$, in other cases LULCC masks changes due to increasing $\mathrm{CO}_{2}$. In general, these compensation/amplification phenomena complicate the use of ETCCDI indices in regional detection and attribution studies. However, they also provide a useful future path for detection and attribution studies since if LULCC is explicitly included, a clearer signal should be possible, providing an improved capacity to attribute observed and modelled trends to known forcings.

Acknowledgements. This work was supported in part through the ARC Centre of Excellence in Climate System Science, which is supported by the Australian Commonwealth Government (CE110001028). MGD and LVA are also supported by ARC Linkage grant LP100200690.

Edited by: L. Ganzeveld

\section{References}

Alexander, L. V., Zhang, X., Peterson, T. C., Caesar, J., Gleason, B., Klein Tank, A. M. G., Haylock, M., Collins, D., Trewin, B., Rahimzadeh, F., Tagipour, A., Rupa Kumar, K., Revadekar, J., Griffiths, G., Vincent, L., Stephenson, D. B., Burn, J., Aguilar, E., Brunet, M., Taylor, M., New, M., Zhai, P., Rusticucci, M., and Vazquez-Aguirre, J. L.: Global observed changes in daily climate extremes of temperature and precipitation, J. Geophys. Res., 111, D05109, doi:10.1029/2005jd006290, 2006.

Arnfield, A. J.: Two decades of urban climate research: A review of turbulence, exchanges of energy and water, and the urban heat island, Int. J. Climatol., 23, 1-26, 2003.

Avila, F. B., Pitman, A. J., Donat, M. G., Alexander, L. V., and Abramowitz, G.: Climate model simulated changes in temperature extremes due to land cover change, J. Geophys. Res., 117, D04108, doi:10.1029/2011jd016382, 2012.

Bala, G., Caldeira, K., Wickett, M., Phillips, T. J., Lobell, D. B., Delire, C., and Mirin, A.: Combined climate and carbon-cycle effects of large-scale deforestation, Proc. Natl. Acad. Sci., 104, 6550-6555, doi:10.1073/pnas.0608998104, 2007.

Boisier, J.-P., de Noblet-Ducoudré, N., Pitman, A. J., Cruz, F., Delire, C., van den Hurk, B. J. J. M., van der Molen,
M. K., Müller, C., and Voldoire, A.: Attributing the biogeophysical impacts of Land-Use induced Land-Cover Changes on surface climate to specific causes. Results from the first LUCID set of simulations, J. Geophys. Res., 117, D12116, doi:10.1029/2011JD017106, 2012.

Bonan, G. B.: Forests and Climate Change: Forcings, Feedbacks, and the Climate Benefits of Forests, Science, 320, 1444-1449, doi:10.1126/science.1155121, 2008.

Caesar, J., Alexander, L., and Vose, R.: Large-scale changes in observed daily maximum and minimum temperatures: Creation and analysis of a new gridded data set, J. Geophys. Res., 111, D05101, doi:10.1029/2005jd006280, 2006.

Chang, H.-I., Niyogi, D., Kumar, A., Kishtawal, C. M., Dudhia, J., Chen, F., Mohanty, U. C., and Shepherd, M.: Possible relation between land surface feedback and the post-landfall structure of monsoon depressions, Geophys. Res. Lett., 36, L15826, doi:10.1029/2009g1037781, 2009.

Davin, E. L. and De Noblet-Ducoudré, N.: Climatic Impact of Global-Scale Deforestation: Radiative versus Nonradiative Processes, J. Climate, 23, 97-112, 2010.

DeAngelis, A., Dominguez, F., Fan, Y., Robock, A., Kustu, M. D., and Robinson, D.: Evidence of enhanced precipitation due to irrigation over the Great Plains of the United States, J. Geophys. Res., 115, D15115, doi:10.1029/2010JD013892, 2010.

de Noblet-Ducoudré, N., Boisier, J.-P., Pitman, A., Bonan, G. B., Brovkin, V., Cruz, F., Delire, C., Gayler, V., van den Hurk, B. J. J. M., Lawrence, P. J., van der Molen, M. K., Müller, C., Reick, C. H., Strengers, B. J., and Voldoire, A.: Determining robust impacts of land-use induced land-cover changes on surface climate over North America and Eurasia; Results from the first set of LUCID experiments, J. Climate, 25, 3261-3281, doi:10.1175/jcli-d11-00338.1, 2012.

Deo, R. C., Syktus, J. I., McAlpine, C. A., Lawrence, P. J., McGowan, H. A., and Phinn, S. R.: Impact of historical land cover change on daily indices of climate extremes including droughts in eastern Australia, Geophys. Res. Lett., 36, L08705, doi:10.1029/2009GL037666, 2009.

Douglas, E. M., Beltrán-Przekurat, A., Niyogi, D., Pielke Sr., R. A., Vörösmarty, C. J.: The impact of agricultural intensification and irrigation on land-atmosphere interactions and Indian monsoon precipitation - A mesoscale modeling perspective, Global Planet. Change, 67, 117-128, doi:10.1016/j.gloplacha.2008.12.007, 2009.

Feddema, J. J., Oleson, K. W., Bonan, G. B., Mearns, L. O., Buja, L. E., Meehl, G. A., and Washington, W. M.: The Importance of land-cover change in simulating future climates, Science, 310, 1674-1678, doi:10.1126/science.1118160, 2005.

Findell, K. L., Pitman, A. J., England, M. H., and Pegion, P. J.: Regional and Global Impacts of Land Cover Change and Sea Surface Temperature Anomalies, J. Climate, 22, 3248-3269, 2009.

Forster, P., Ramaswamy, V., Artaxo, P., Berntsen, T., Betts, R., Fahey, D. W., Haywood, J., Lean, J. L., Lowe, D. C., Myhre, G., Nganga, J., Prinn, R., Raga, G., Schulz, M., and Van Dorland, $\mathrm{R}$.: Changes in atmospheric Cconstituents and in radiative forcing, in: Climate Change 2007: The Physical Science Basis. Contribution of Working Group I to the Fourth Assessment Report of the Intergovernmental Panel on Climate Change, edited by: Solomon, S., Qin, D., Manning, M., Chen, Z., Marquis, M., Averyt, K. B., Tignor, M., and Miller, H. L., CUP, Cambridge, UK 
and New York, NY, USA, 2007.

Gero, A. F. and Pitman, A. J.: The Impact of Land Cover Change on a Simulated Storm Event in the Sydney Basin, J. Appl. Meteorol. Climatol., 45, 283-300, doi:10.1175/JAM2337.1, 2006.

Goldewijk, K. K.: Estimating global land use change over the past 300 years: The HYDE Database, Global Biogeochem. Cy., 15, 417-433, doi:10.1029/1999gb001232, 2001.

Hazeleger, W., Wang, X., Severijns, C., Ştefănescu, S., Bintanja, R., Sterl, A., Wyser, K., Semmler, T., Yang, S., van den Hurk, B., van Noije, T., van der Linden, E., and van der Wiel, K.: EC-Earth V2.2: description and validation of a new seamless earth system prediction model, Clim. Dynam., 1-19, doi:10.1007/s00382011-1228-5, 2011.

IPCC: Summary for Policymakers, in: Managing the Risks of Extreme Events and Disasters to Advance Climate Change Adaptation. A Special Report of Working Groups I and II of the Intergovernmental Panel on Climate Change, edited by: Field, C. B., Barros, V., Stocker, T. F., Qin, D., Dokken, D. J., Ebi, K. L., Mastrandrea, M. D., Mach, K. J., Plattner, G.-K., Allen, S. K., Tignor, M., and Midgley, P. M., CUP, Cambridge, UK, and New York, NY, USA, 1-19, 2012.

Klein Tank, A. M. G. and Zwiers, F. W.: Guidelines on Analysis of extremes in a changing climate in support of informed decisions for adaptation World Meteorological Organization, Geneva, Switzerland, 56, 2009.

Krinner, G., Viovy, N., de Noblet-Ducoudré, N., Ogeé, J., Polcher, J., Friedlingstein, P., Ciais, P., Sitch, S., and Prentice, I. C.: A dynamic global vegetation model for studies of the coupled atmosphere-biosphere system, Global Biogeochem. Cy., 19, GB1015, doi:10.1029/2003gb002199, 2005.

Lawrence, P. J. and Chase, T. N.: Investigating the climate impacts of global land cover change in the community climate system model, Int. J. Climatol., 30, 2066-2087, doi:10.1002/joc.2061, 2010.

Levis, S.: Modeling vegetation and land use in models of the Earth System, WIRES: Climate Change, 1, 840-856, doi:10.1002/wcc.83, 2010.

Lobell, D., Bala, G., Mirin, A., Phillips, T., Maxwell, R., and Rotman, D.: Regional Differences in the Influence of Irrigation on Climate, J. Climate, 22, 2248-2255, 2009.

Marti, O., Braconnot, P., Dufresne, J. L., Bellier, J., Benshila, R., Bony, S., Brockmann, P., Cadule, P., Caubel, A., Codron, F., de Noblet, N., Denvil, S., Fairhead, L., Fichefet, T., Foujols, M. A., Friedlingstein, P., Goosse, H., Grandpeix, J. Y., Guilyardi, E., Hourdin, F., Idelkadi, A., Kageyama, M., Krinner, G., Lévy, C., Madec, G., Mignot, J., Musat, I., Swingedouw, D., and Talandier, C.: Key features of the IPSL ocean atmosphere model and its sensitivity to atmospheric resolution, Clim. Dynam., 34, 1-26, doi:10.1007/s00382-009-0640-6, 2010.

Niyogi, D., Pyle, P., Lei, M., Arya, S. P., Kishtawal, C. M., Shepherd, M., Chen, F., and Wolfe, B.: Urban Modification of Thunderstorms: An Observational Storm Climatology and Model Case Study for the Indianapolis Urban Region, J. Appl. Meteorol. Climatol., 50, 1129-1144, doi:10.1175/2010jamc1836.1, 2011.

Pielke, R. A., Sr.: Influence of the spatial distribution of vegetation and soils on the prediction of cumulus convective rainfall, Rev. Geophys., 39, 151-177, doi:10.1029/1999rg000072, 2001.

Pielke, R. A., Sr., Pitman, A., Niyogi, D., Mahmood, R., McAlpine, C., Hossain, F., Goldewijk, K. K., Nair, U., Betts,
R., Fall, S., Reichstein, M., Kabat, P., and de Noblet, N.: Land use/land cover changes and climate: modeling analysis and observational evidence, WIRES: Climate Change, 2, 828-850, doi:10.1002/wcc.144, 2011.

Pitman, A. J.: The evolution of, and revolution in, land surface schemes designed for climate models, Int. J. Climatol., 23, 479510, 2003.

Pitman, A. J., de Noblet-Ducoudré, N., Cruz, F. T., Davin, E. L., Bonan, G. B., Brovkin, V., Claussen, M., Delire, C., Ganzeveld, L., Gayler, V., van den Hurk, B. J. J. M., Lawrence, P. J., van der Molen, M. K., Müller, C., Reick, C. H., Seneviratne, S. I., Strengers, B. J., and Voldoire, A.: Uncertainties in climate responses to past land cover change: First results from the LUCID intercomparison study, Geophys. Res. Lett., 36, L14814, doi:10.1029/2009g1039076, 2009.

Pitman, A. J., Avila, F. B., Abramowitz, G., Wang, Y. P., Phipps, S. J. ,and de Noblet-Ducoudré, N.: Importance of background climate in determining impact of land-cover change on regional climate, Nature Clim. Change, 1, 472-475, 2011.

Puma, M. J. and Cook, B. I.: Effects of irrigation on global climate during the 20th century, J. Geophys. Res., 115, D16120, doi:10.1029/2010JD014122, 2010.

Raddatz, T., Reick, C., Knorr, W., Kattge, J., Roeckner, E., Schnur, R., Schnitzler, K. G., Wetzel, P., and Jungclaus, J.: Will the tropical land biosphere dominate the climate-carbon cycle feedback during the twenty-first century?, Clim. Dynam., 29, 565-574, doi:10.1007/s00382-007-0247-8, 2007.

Ramankutty, N. and Foley, J. A.: Estimating historical changes in global land cover: Croplands from 1700 to 1992, Global Biogeochem. Cy., 13, 997-1027, 1999.

Roeckner, E., Brokopf, R., Esch, M., Giorgetta, M., Hagemann, S., Kornblueh, L., Manzini, E., Schlese, U., and Schulzweida, U.: Sensitivity of Simulated Climate to Horizontal and Vertical Resolution in the ECHAM5 Atmosphere Model, J. Climate, 19, 3771-3791, doi:10.1175/jcli3824.1, 2006.

Salas-Mélia, D., Chauvin, F., Déqué, M., Douville, H., Guérémy, J. F., Marquet, P., Planton, S., Royer, J. F., and Tyteca, S.: Description and validation of the CNRM-CM3 global coupled climate model, CNRM working note 103, available at: http://www.cnrm. meteo.fr/scenario2004/paper_cm3.pdf, 2005.

Seneviratne, S. I., Luthi, D., Litschi, M., and Schar, C.: Landatmosphere coupling and climate change in Europe, Nature, 443 , 205-209, 2006.

Seneviratne, S. I., Corti, T., Davin, E. L., Hirschi, M., Jaeger, E. B., Lehner, I., Orlowsky, B., and Teuling, A. J.: Investigating soil moisture-climate interactions in a changing climate: A review, Earth-Sci. Rev., 99, 125-161, doi:10.1016/j.earscirev.2010.02.004, 2010.

Shepherd, J. M.: A review of current investigations of urbaninduced rainfall and recommendations for the future, Earth Interact., 9, paper 12, 1-27, 2005 .

Stefanon, M., Drobinski, P., D'Andrea, F., and de NobletDucoudré, N.: Effects of interactive vegetation phenology on the 2003 summer heat waves, J. Geophys. Res., in press, doi:10.1029/2012JD018187, 2012.

Teuling, A. J., Seneviratne, S. I., Stockli, R., Reichstein, M., Moors, E., Ciais, P., Luyssaert, S., van den Hurk, B., Ammann, C., Bernhofer, C., Dellwik, E., Gianelle, D., Gielen, B., Grunwald, T., Klumpp, K., Montagnani, L., Moureaux, C., Sottocornola, M., 
and Wohlfahrt, G.: Contrasting response of European forest and grassland energy exchange to heatwaves, Nat. Geosci., 3, 722727, 2010.

van der Molen, M. K., van den Hurk, B. J., and Hazeleger, W.: A dampened land use change climate response towards the tropics, Clim. Dynam., 37, 2035-2043, doi:10.1007/s00382-011-1018-0, 2011.

Voldoire, A.: Quantifying the impact of future land-use changes against increases in GHG concentrations, Geophys. Res. Lett., 33, L04701, doi:10.1029/2005g1024354, 2006.
Zhang, X., Alexander, L., Hegerl, G. C., Jones, P., Tank, A. K., Peterson, T. C., Trewin, B., and Zwiers, F. W.: Indices for monitoring changes in extremes based on daily temperature and precipitation data, WIRES: Climate Change, 2, 851-870, doi:10.1002/wcc.147, 2011.

Zhao, M. and Pitman, A. J.: The impact of land cover change and increasing carbon dioxide on the extreme and frequency of maximum temperature and convective precipitation, Geophys. Res. Lett., 29, 1078, doi:10.1029/2001g1013476, 2002. 